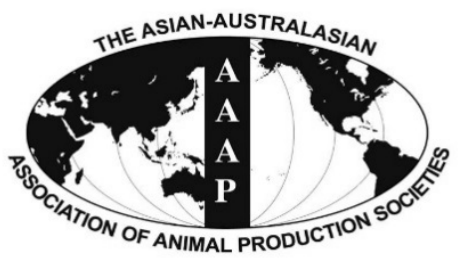

Open Access

Asian Australas. J. Anim. Sci.

Vol. 29, No. 4 : 580-585 April 2016

http://dx.doi.org/10.5713/ajas.15.0383

www.ajas.info

pISSN 1011-2367 elSSN 1976-5517

\title{
Factors in Dry Period Associated with Intramammary Infection and Subsequent Clinical Mastitis in Early Postpartum Cows
}

\author{
Kansuda Leelahapongsathon, Tipapun Piroon, Wasana Chaisri, and Witaya Suriyasathaporn* \\ Department of Food Animal Clinics, Faculty of Veterinary Medicine, Chiang Mai University, \\ Mae Hea, Chiang Mai 50100, Thailand
}

\begin{abstract}
The objective of this study was to determine cow characteristics and farm management factors during the dry period associated with early postparturient intramammary infection (IMI) and subsequent clinical mastitis (CM). Data were collected three times: before drying off (P1), during the dry period (P2), and 5 to 14 days after calving (P3), using questionnaires and farm investigation. Milk samples were aseptically collected for bacterial identification at P1 and P3. Factors associated with IMI and CM were analyzed using multiple logistic regression models. The final model showed that IMI in early postpartum was significantly associated with full insertion of dry cow antibiotic, dry cows in barns with a combination of tie and free stalls, body condition score (BCS) in dry period and after calving, and milk yield before drying off. For IMI cows, factors significantly associated with clinical expression of mastitis were having daily barn cleaning, teat disinfected with alcohol before administration of dry cow therapy, BCS before drying off, milk yield before drying off, and days in milk at drying off. In conclusion, both cow and farm management factors are associated with the IMI rate and subsequent expression of clinical signs of mastitis in early postpartum cows. (Key Words: Dry Period, Clinical Mastitis, Intramammary Infection)
\end{abstract}

\section{INTRODUCTION}

Mastitis is one of the most important problems in the dairy industry, causing economic loss and milk quality reduction. Mastitis is mainly caused by bacterial intramammary infection (IMI). The rate of IMI has been found to be seven times greater during the early dry period than during lactation (Smith et al., 1985). The incidence of IMI increases in both the early and late dry periods (Oliver et al., 1983; Smith et al., 1985; Eberhart, 1986; Robert et al., 2006) because of changes in the anatomy and function of the mammary gland (Church et al., 2008). Intramammary infection during the dry period increases the risk of clinical mastitis (CM) in the early subsequent lactation (Pantoja et al., 2009), especially in the first 30 to 60 days after calving (Barker et al., 1998). Clinical mastitis occurs mostly in early

\footnotetext{
* Corresponding Author: Witaya Suriyasathaporn. Tel: +66-53-94 8023, Fax: +66-53-274710, E-mail: Suriyasathaporn@hotmail.com Submitted May 2, 2015; Revised Jun. 8, 2015; Accepted Jul. 10, 2015
}

lactation and is caused by environmental pathogens such as Coliform (Escherichia coli) and Streptococcus spp. Factors affecting the clinical expression of mastitis also include the rate of bacterial exposure of the mammary glands and the efficiency of udder defense mechanisms.

Sources of IMI during the dry period originated either from bacteria remaining in the udder during lactation, or new IMI during the dry period (Green et al., 2007). Approximately $10 \%$ to $17 \%$ of quarters developed new IMI during the dry period, and most infections were caused by environmental organisms (Pantoja et al., 2009). The probability of new IMI in dairy cattle depends on the rate of bacterial exposure, the efficiency of udder defense mechanisms, and the use of antibiotic dry-cow therapy (Green et al., 2007).

Dry period management is important in eliminating existing IMI and preventing new IMI. Dry cow therapy and antibiotic treatment at the end of lactation are effective tools in both regards (Smith et al., 1985; Eberhart, 1986; Berry and Hillerton, 2002). Other management factors, such as 
increased parity and somatic cell count $\geq 200,000$ cells $/ \mathrm{mL}$ before drying off, were risk factors of CM post partum (Green et al., 2002; Green et al., 2007; Pantoja et al., 2009). In Thailand, the mastitis control program including dry cow therapy has been widely used in most farms. However, the postpartum mastitis problem that persists might indicate that existing knowledge does not explain all the mastitis risk factors for smallholder dairy farms in a tropical environment.

The objective of this study was therefore to determine the farm management factors during the dry period, and the cow characteristics, associated with early postparturient IMI and subsequent CM in IMI cows in smallholder dairy cows in a tropical environment.

\section{MATERIALS AND METHODS}

\section{Farm and cow selection and data collection}

Twenty-two smallholder dairy farms in Mae-Wang and Mae-Joe dairy co-operatives, Chiang Mai Province, Thailand, participated in the study. After enrollment, farms having pregnant cows expected to start drying-off in July to October 2009, with drying off periods ranging from 40 to 80 days, were included. Before and during drying off periods, cows with $\mathrm{CM}$ or any health disorder were excluded from the study. All farms had average herd sizes ranging from 10 to 26 milking cows. The management of all farms included the use of bucket-type milking machines, milking twice a day, and using commercial concentrates and local roughages from agricultural by-products. The commercial concentrates, which originated from both nationwide and local companies (for example Betagro Public Company Limited, CPF Thailand Public Company Limited, and Chokchai Ranch Company Limited), contained protein $14 \%$ to $18 \%$, fat $3 \%$, fiber $12 \%$ to $13 \%$, and humidity $13 \%$. Most roughages were local post harvests agriculture and by-product from food companies including; corn silage (composition of dry matter: protein $7 \%$, fat $1.2 \%$, and fiber $74 \%$ ), rice straw (composition of dry matter: protein $3.1 \%$, fat $1.7 \%$, fiber $27.7 \%$, starch $41.8 \%$, and mineral $16.6 \%$ ), and corn stalk (composition of dry matter: protein $1.4 \%$, fat $0.4 \%$, fiber $4.3 \%$, starch $6.6 \%$, and mineral 1.6\%).

Data were collected at 1-14 days before drying off (P1), during the dry period (P2) and 5 to 14 days after calving (P3), from either questionnaires or farm investigation. The data included cow characteristics and dry cow management. Factors of cow characteristics were parity; \% of crossbred Holstein-Friesian; body condition scores (BCS) before drying off, in dry period, and after calving; days in milk at drying off; last milk production before drying off; history of prior mastitis problems before drying off; and illness history before drying off. Dry cow management factors were types of dry cow antibiotic uses, use of alcohol before intramammary infusion, methods of administering intramammary product (full insertion, insertion the whole length of the syringe cannula into the teat orifice and expelling contents; or partial insertion, insertion 2 to $3 \mathrm{~mm}$ of the tip of the syringe cannula into the teat orifice and expelling contents), use of antiseptic teat dipping immediately after intramammary infusion, and vitamin $\mathrm{ADE}$ administration at drying off. At the middle of the dry period (P2), management of the drying off cows was investigated to collect data e.g. separation of dry cows from lactating cows, moving cows into separated calving pens, type of barn (tie stall, free stall, mixed type), barn condition (clean, filthy, damp, or muddy), and barn cleaning )daily, rarely). After calving, cows were observed for any signs of $\mathrm{CM}$ by farmers. Clinical mastitis was defined when a cow had udder changes (hot, swelling, redness of udder) and/or abnormal milk (color change, presence of blood, pus or clotted milk).

\section{Milk sample collection and bacterial identification}

To define postpartum IMI cows, milk samples were collected twice: at 1 to 14 days before expected drying off date (P1) and at 5 to 14 days after calving (P3). Milk samples were aseptically collected from each quarter and stored at $4^{\circ} \mathrm{C}$ to $8^{\circ} \mathrm{C}$. Bacteriology identification was performed within 4 hours after collection according to standard procedure described by National Mastitis Council's guidelines (NMC, 1999). Briefly, samples were mixed together, and ten microliters of each milk sample were cultured on a $5 \%$ bovine blood agar plate (blood agar base; Oxoid, distilled water, and $5 \% \mathrm{v} / \mathrm{v}$ bovine blood) and incubated at $37^{\circ} \mathrm{C}$ for 24 to 48 hours. After incubation, microorganisms were primarily identified by colony morphology, hemolysis test, catalase reaction, and gram staining. Other biochemical tests for different bacterial species were performed.

An IMI was defined as the presence of at least one colony of one to two species of bacteria (Green et al., 2002). Samples that contained three or more bacterial species were considered to be contaminated. Isolates of either Streptococcus agalactiae or Staphylococcus aureus, however, were always defined as IMI (NMC, 1999).

\section{Statistical analysis}

Data were described by means and standard deviation (SD) for continuous variables and frequencies for categorical variables. Cow characteristics (number of cows, \% Holstein-Friesian, parity, milk productions, milk yield at drying off, days in milk, BCS before drying off, BCS at dry period, BCS after calving, and dry period) in 3 groups of cow (uninfected, IMI with CM, and IMI without $\mathrm{CM}$ ) were analyzed by analysis of variance with Duncan's 
multiple test to compare differences among groups of cows. Statistical analyses were performed by creating multiple logistic models: i( an IMI model and ii) a CM model. For the IMI model, IMI variable, as a dependent variable, was determined as "positive" when having positive bacterial identification and/or CM after calving. For CM model, only data from IMI quarters were used, and CM variable was a dependent variable. The CM variable was defined "positive" when the IMI quarters showed any signs of CM. Independent variables were cow characteristics and dry cow management factors. The logistic models were created by the free entering method. All factors were entered and remained in the model when $\mathrm{p}<0.15$ indicated by likelihood ratio tests. Odds ratio (OR) was used to describe the direction of relationship between dependent and independent variables. The $\mathrm{OR}>1$ indicated that the specified level had more risk to become IMI or CM than the reference value (Green et al., 2007; Pantoja et al., 2009).

\section{RESULTS}

From a total of 22 small dairy farms, 48 clinically healthy cows without CM were included in the study. Parities of the cows ranged between one to eight, and the means (SD) of parities were 2.07 (2.12), 2.6 (1.9), and 2.04 (0.71) for uninfected cows, IMI with CM cows, and IMI without CM cows, respectively (Table 1). Cow characteristics of this study are shown in Table 1. Cows with both IMI and subsequently CM had the lowest milk yield at drying off, the highest day in milk and the lowest BCS before drying off. However, no significant difference was observed in the tested characteristics among groups of cows $(\mathrm{p}>0.05)$.

Of the 48 clinically healthy cows without CM (184 quarters), percentages of quarters with culture-positive quarter sample (or IMI) before drying off and after calving were $59.24 \%$ and $33.15 \%$, respectively. From IMI quarter, quarters with $\mathrm{CM}$ after calving were $26.23 \%$. Numbers of
Table 2. Bacterial isolated from milk samples at 14 days before drying off and 5-14 days after calving

\begin{tabular}{lcc}
\hline & \multicolumn{2}{c}{ Number of cases (\%) } \\
\cline { 2 - 3 } Bacterial species & $\begin{array}{c}\text { Before } \\
\text { drying off }\end{array}$ & $\begin{array}{c}\text { After } \\
\text { calving }\end{array}$ \\
\hline Corynebacterium spp. & $37(33.33)$ & $28(51.85)$ \\
Coagulase-negative staphylococci (CNS) & $46(41.44)$ & $10(18.52)$ \\
Other environmental streptococci & $10(9.01)$ & $1(1.85)$ \\
Streptococcus dysgalactiae & $6(5.41)$ & $4(7.41)$ \\
Streptococcus bovis & $3(2.70)$ & $1(1.85)$ \\
Staphylococcus aureus & $3(2.70)$ & - \\
Bacillus spp. & $1(0.90)$ & $4(7.41)$ \\
Yeast & - & $5(9.26)$ \\
Streptococcus uberis & $3(2.70)$ & $1(1.85)$ \\
Streptococcus agalactiae & $1(0.90)$ & - \\
Salmonella spp. & $1(0.90)$ & - \\
Total & $111(100)$ & $54(100)$ \\
\hline
\end{tabular}

bacteria isolated from milk samples separated for each species are shown in Table 2. Most isolates found were environmental pathogens. The most microorganisms isolated before drying-off were coagulase-negative staphylococci (CNS; 41.44\%). Corynebacterium spp. isolates were found in high percentages both before dryingoff $(33.33 \%)$, and after calving (51.85\%). However, only before drying-off, Staphylococcus aureus and Streptococcus agalactiae were found with the percentages of $2.7 \%$ and $0.9 \%$, respectively.

Factors during dry period in association with intramammary infection in early postpartum cows

The final model of factors associated with IMI after calving is shown in Table 3. Factors associated with IMI were full insertion of dry cow antibiotic $(p=0.03)$, dry cows in barns with a combination of tie stalls and free stalls $(p=0.01)$, BCS in dry period $) p=0.04($, BCS after calving $(p=0.02)$ and milk yield before drying off $) p<0.01($. The full insertion of dry cow antibiotic increased the risk of

Table 1. Cow characteristic analysis from uninfected cows, intramammary infected (IMI) with or without clinical mastitis (CM)

\begin{tabular}{lccc}
\hline \multirow{2}{*}{ cow characteristic } & \multicolumn{2}{c}{ Average )SD) } \\
\cline { 2 - 4 } & Uninfected cows & IMI with CM & IMI without CM \\
\hline Number of cows (cows) & 15 & 10 & 23 \\
HF (\%) & $88.83(0.18)$ & $88.85(8.15)$ & $91.16(12.55)$ \\
Parity & $2.07(2.12)$ & $2.6(1.9)$ & $2.04(0.71)$ \\
Milk productions (kg/d) & $14.92(2.12)$ & $14.25(3.15)$ & $15.26(2.12)$ \\
Milk yield at drying off (kg) & $6.13(1.41)$ & $4.11(2.15)$ & $5.59(1.41)$ \\
Days in milk (d) & $365.6(96.2)$ & $385(108.17)$ & $327.52(78.49)$ \\
BCS before drying off & $2.92(0.18)$ & $2.7(0.28)$ & $2.95(0.53)$ \\
BCS at dry period & $2.9(0)$ & $2.9(0.47)$ & $3.07(0.18)$ \\
BCS after calving & $2.93(0)$ & $2.83(0.38)$ & $2.88(0.35)$ \\
Dry period (d) & $64.33(7.78)$ & $62.1(19.37)$ & $61.22(4.24)$
\end{tabular}

SD, standard deviation; HF, Holstein-Friesian; BCS, body condition score.

No significant difference was observed in the tested characteristics $(\mathrm{p}>0.05)$. 
Table 3. The final model indicating factors associated with intramammary infection in early postpartum cows

\begin{tabular}{|c|c|c|c|c|c|}
\hline \multicolumn{2}{|l|}{ Factors } & Estimate & $\mathrm{SE}$ & p-value & Odds ratio \\
\hline \multicolumn{2}{|c|}{ Full insertion of dry cow antibiotic } & 0.48 & 0.22 & 0.03 & 2.62 \\
\hline \multirow[t]{3}{*}{ Barn type } & Free-stall & 0.53 & 0.44 & 0.23 & 2.86 \\
\hline & Mixed type & 0.62 & 0.25 & 0.01 & 3.47 \\
\hline & Tie stall & \multicolumn{4}{|c|}{ Reference } \\
\hline \multicolumn{2}{|c|}{ BCS in dry period } & 1.29 & 0.62 & 0.04 & 3.61 \\
\hline \multicolumn{2}{|c|}{ BCS after calving } & -1.46 & 0.64 & 0.02 & 0.23 \\
\hline \multicolumn{2}{|c|}{ Milk yield before drying off } & -0.21 & 0.08 & $<0.01$ & 0.81 \\
\hline
\end{tabular}

SE, standard error; BCS, body condition score.

getting IMI by about 2.6 times compared to partial insertion $(\mathrm{OR}=2.62)$. Dry cows in barns with a combination of tie stalls and free stalls were at increased risk of IMI (OR = 3.47). Cows with higher BCS in dry period $(\mathrm{OR}=3.61)$, but with lower BCS after calving $(\mathrm{OR}=0.23)$ had more risk of IMI. Higher amount of milk yield before drying off decreased risk of IMI $(\mathrm{OR}=0.81)$.

Factors during dry period associated with subsequent clinical mastitis after intramammary infection in early postpartum cows

The final model of factors associated with clinical expression of mastitis after IMI is presented in Table 4. Factors associated with clinical expression of mastitis after IMI were daily barn cleaning $(p=0.02)$, teat disinfected with alcohol before administration of dry cow therapy $(\mathrm{p}=$ $0.02)$, BCS before drying off $(\mathrm{p}=0.04)$, milk yield before drying off $(\mathrm{p}=0.02)$, and days in milk at drying off $(\mathrm{p}=$ 0.04). Daily barn cleaning $(\mathrm{OR}=0.04)$, teat disinfected with alcohol before administration of dry cow therapy (OR $=0.06)$, higher $\mathrm{BCS}$ before drying off $(\mathrm{OR}=0.11)$, higher milk yield before drying off $(\mathrm{OR}=0.61)$, and lower days in milk at drying off $(\mathrm{OR}=1.01)$ decreased risk of $\mathrm{CM}$ after IMI.

\section{DISCUSSION}

This study was focused on an epidemiology of mastitis in the field by determining the risk factors of IMI and subsequent $\mathrm{CM}$ during transition period of cows. Bacterial identification in the present study followed the standard protocol according to National Mastitis Council's guidelines (NMC, 1999). This protocol has been used in many previous studies, for examples: Church et al. (2008), Pantoja et al. (2009), Suriyasathaporn (2010), Pinedo et al. (2012), Leelahapongsathon et al. (2014). In our study, IMI after calving were $33.15 \%$, in the range of previous reports on early postpartum cows in this area (Chaikhun et al., 2005). Bacteria causing IMI at drying off and after calving were Corynebacterium spp. and CNS. These bacteria were found as the main pathogens causing IMI at drying off and after calving (Sargeant et al., 2001; Green et al., 2002; Pantoja et al., 2009).

As with most infectious diseases, mastitis incidence depends on three components: exposure to microbes, udder defense mechanisms, and environmental risk factors. In the past decade, the standard mastitis control program has provided hygiene and management practices to control IMI (Neave et al., 1969). Intramammary infection in dry periods may result from increased exposure to pathogens. In this study, the full insertion of dry cow antibiotic led to greater risk of IMI. The full insertion caused teat canal lumen dilatation and consequently more susceptibility to bacterial penetration into the udder (Boddie and Nickerson, 1986). Partial insertion (i.e. $<4 \mathrm{~mm}$ ) reduced new IMI rates and increased the cure rate of existing infections, compared with full insertion (Boddie and Nickerson, 1986). Partial insertion results in less of the protective keratin that lines the teat canal being removed, reduces the degree of distension of the canal, and reduces the probability that pathogens are introduced into the mammary gland during infusion (McDougall, 2003). In addition, mixed barn type

Table 4. The final model indicating factors associated with clinical expression of mastitis after intramammary infection in early postpartum cows

\begin{tabular}{|c|c|c|c|c|}
\hline Factors & Estimate & SE & p-value & Odds ratio \\
\hline Daily barn cleaning & -1.64 & 0.7 & 0.02 & 0.04 \\
\hline $\begin{array}{l}\text { Teat disinfected with alcohol } \\
\text { before administration of dry cow therapy }\end{array}$ & -1.42 & 0.59 & 0.02 & 0.06 \\
\hline BCS before drying off & -2.17 & 1.06 & 0.04 & 0.11 \\
\hline Milk yield before drying off (kg) & -0.49 & 0.21 & 0.02 & 0.61 \\
\hline Days in milk at drying off (d) & 0.01 & 0.01 & 0.04 & 1.01 \\
\hline
\end{tabular}

SE, standard error; BCS, body condition score. 
including free-stall type and tie stall type might affect barn cleanliness. Floor cleaning is better in tie stall type than in free-stall type and mixed type. Dry lot location is an important factor in providing an environment with reduced bacterial populations (Jones, 2009). Cow hygiene in dry periods is associated with a decreased rate of infection (Brand et al., 1996; Green et al., 2007).

Risk of CM after IMI was associated with udder defense efficiency (Suriyasathaporn et al., 2000a;b), and including quantity and virulence of intramammary pathogens. From Table 4, factors associated with clinical expression of mastitis after IMI that related to reduced chance of exposure to pathogens, were having daily barn cleaning and teat disinfected with alcohol before administration of dry cow therapy. These factors would provide hygiene in dry cows to prevent new IMI and subsequent CM (Barnouin et al., 2004; Green et al., 2008). However, teat disinfected with alcohol before administration of dry cow therapy was recommended for infusion of dry cow therapy (NMC, 2006). Frequent management of dry-period accommodation was associated with decreased pathogen challenge into udders (Green et al., 2007).

Udder defense plays an important role in protecting and minimizing the expression of clinical symptoms in infected mammary glands (Kehrli and Shuster, 1994). High BCS before dry period and after calving was associated with a reduced risk of both IMI after calving and subsequent clinical expression of mastitis in the IMI quarters. Low BCS might indicate poor farm management and inadequate nutrition for milking cows that related to increase susceptible to CM, for example inadequate levels of vitamin $\mathrm{E}$ and selenium causing impairment of udder defense mechanism postpartum (Hogan et al., 1993; O'Rourke, 2009). In addition, the previous study found that cows with low BCS had more risk of subsequent CM than cows with BCS 3 to 3.5, because of hyperketonemia in most low BCS cows (Suriyasathaporn et al., 2000a;b).

Moreover, high BCS in dry period was associated with an increased risk of IMI after calving. These results corresponded with the studies of Valde et al. (2007). These authors reported that herds with low incidence of mastitis had lower average BCS during 30 days before calving than high mastitis incidence herds. The fatter cows during calving periods have a greater chance of losing weight and body integrity than thinner cows. This might be associated with hyperketonemia in cows after calving that could decrease the efficiency of udder defense mechanisms (Suriyasathaporn et al., 2000a).

Regarding milk yield before drying off, our study shows that higher milk yield before drying off was related to either lower IMI or lower CM incidence after IMI (Tables 3 and 4). Low milk yield before drying off was associated with decreased udder defense efficiency (Natzke et al., 1975).
This is in agreement with information presented by Pinedo et al. (2012), who reported that cows with lower milk production in the previous lactation had higher risk of clinical and subclinical mastitis after calving compared with high-producing cows. In addition, cows with higher days in milk were at increased risk of clinical expression of mastitis. The high days in milk indicated a lack of attention to cows during end of lactation and might also relate to decreased udder defense efficiency because of long term of lactation.

In conclusion, both cow and farm management factors including insertion of dry cow antibiotic are associated with IMI rate and subsequent expression of clinical signs of mastitis in early postpartum cows.

\section{CONFLICT OF INTEREST}

We certify that there is no conflict of interest with any financial organization regarding the material discussed in the manuscript.

\section{ACKNOWLEDGMENTS}

This research was funded by Thailand Research Fund; The Royal Golden Jubilee Ph.D. Program and Faculty of Veterinary Medicine, Chiang Mai University. We would like to thank Tawatchai Singhla, Sonthaya Umsum-arng and dairy farmers in Mae-Wang and Mae-Joe dairy cooperatives, Chiang Mai for their grateful participation. We are also grateful to for Saowaratcharee Rin-ut; a scientist in department of food animal clinic for her support with laboratory procedures.

\section{REFERENCES}

Barker, A. R., F. N. Schrick, M. J. Lewis, H. H. Dowlen, and S. P. Oliver. 1998. Influence of clinical mastitis during early lactation on reproductive performance of jersey cows. J. Dairy Sci. 81:1285-1290.

Barnouin, J., M. Chassagne, S. Bazin, and D. Boichard. 2004. Management practices from questionnaire surveys in herds with very low somatic cell score through a national mastitis program in France. J. Dairy Sci. 87:3989-3999.

Berry, E. A. and J. E. Hillerton. 2002. The effect of selective dry cow treatment on new intramammary infections. J. Dairy Sci. $85: 112-21$

Boddie, R. L. and S. C. Nickerson. 1986. Dry cow therapy: Effects of method of drug administration on occurrence of intramammary infection. J. Dairy Sci. 69:253-257.

Brand, A., J. P. T. M. Noordhuizen, and Y. H. Schukken. 1996. Herd Health and Production Management in Dairy Practice. 2nd ed. Wageningen Pers, Wageningen, The Netherlands.

Chaikhun, T., S. Surawong, S. Boonyayatraand, and W. Suriyasathaporn. 2005. Factors associated with subclinical mastitis in postparturient lactating cows in Chiang Mai and Lumphun provinces. Chiang Mai Vet. J. 3:31-42. 
Church, G. T., L. K. Fox, C. T. Gaskins, D. D. Hancock, and J. M. Gay. 2008. The effect of a shortened dry period on intramammary infections during the subsequent lactation. J. Dairy Sci. 91:4219-4225.

Eberhart, R. J. 1986. Management of dry cows to reduce mastitis. J. Dairy Sci. 69:1721-1732.

Green, M. J., A. J. Bradley, G. F. Medley, and W. J. Browne. 2007. Cow, farm, and management factors during the dry period that determine the rate of clinical mastitis after calving. J. Dairy Sci. 90:3764-3776.

Green, M. J., A. J. Bradley, G. F. Medley, and W. J. Browne. 2008. Cow, farm, and herd management factors in the dry period associated with raised somatic cell counts in early lactation. J. Dairy Sci. 91:1403-1415.

Green, M. J., L. E. Green, G. F. Medley, Y. H. Schukken, and A. J. Bradley. 2002. Influence of dry period bacterial intramammary infection on clinical mastitis in dairy cows. J. Dairy Sci. 85:2589-2599.

Hogan, J. S., W. P. Weiss, and K. L. Smith. 1993. Role of vitamin $\mathrm{E}$ and selenium in host defense against mastitis. J. Dairy Sci. 76:2795-2803.

Jones, G. M. 2009. Proper Dry Cow Management Critical for Mastitis Control. Virginia Cooperative Extension, Virginia Polytechnic Institute and State University, Blacksburg, VA, USA. pp. 404-212.

Kehrli, M. E. and D. E. Shuster. 1994. Factors affecting milk somatic cells and their role in health of the bovine mammary gland. J. Dairy Sci. 77:619-627.

Leelahapongsathon, K., Y. H. Schukken, and W. Suriyasathaporn. 2014. Quarter, cow, and farm risk factors for intramammary infections with major pathogens relative to minor pathogens in Thai dairy cows. Trop. Anim. Health Prod. 46:1067-1078.

McDougall, S. 2003. Management factors associated with the incidence of clinical mastitis over the non-lactation period and bulk tank somatic cell count during the subsequent lactation. NZ Vet. J. 51:63-72.

National Mastitis Council (NMC). 1999. Laboratory Handbook on Bovine Mastitis. NMC Inc., Madison, WI, USA.

National Mastitis Council (NMC) Inc. 2006. Dry Cow Therapy. https://nmconline.org/drycow.htm. Accessed June 14, 2015

Natzke, R. P., R. W. Everett, and D. R. Bray. 1975. Effect of drying off practices on mastitis infection. J. Dairy Sci. 58:1828-1835.
Neave, F. K., F. H. Dodd, R. G. Kingwill, and D. R. Westgarth. 1969. Control of mastitis in the dairy herd by hygiene and management. J. Dairy Sci. 52:696-707.

Oliver, S. P. and B. A. Mitchell. 1983. Susceptibility of bovine mammary gland to infections during the dry period. J. Dairy Sci. 66:1162-1166.

O'Rourke, D. 2009. Nutrition and udder health in dairy cows: A review. Irish Vet. J. 62:15-20.

Pantoja, J. C., C. Hulland, and P. L. Ruegg. 2009. Somatic cell count status across the dry period as a risk factor for the development of clinical mastitis in the subsequent lactation. J. Dairy Sci. 92:139-148.

Pinedo, P. J., C. Fleming, and C. A. Risco. 2012. Events occurring during the previous lactation, the dry period, and peripartum as risk factors for early lactation mastitis in cows receiving 2 different intramammary dry cow therapies. J. Dairy Sci. 95:7015-7026.

Robert, A., H. Seegers, and N. Bareille. 2006. Incidence of intramammary infections during the dry period without or with antibiotic treatment in dairy cows - a quantitative analysis of published data. Vet Res. 37:25-48.

Sargeant, J. M., K. E. Leslie, J. E. Shirley, B. J. Pulkrabek, and G. H. Lim. 2001. Sensitivity and specificity of somatic cell count and California mastitis test for identifying intramammary infection in early lactation. J. Dairy Sci. 84:2018-2024.

Smith, K. L., D. A. Todhunter, and P. S. Schoenberger, 1985. Environmental pathogens and intramammary infection during the dry period. J. Dairy Sci. 68:402-417.

Suriyasathaporn, W. 2010. Milk quality and antimicrobial resistance against mastitis pathogens after changing from a conventional to an experimentally organic dairy farm. Asian Australas. J. Anim. Sci. 23:659-664.

Suriyasathaporn, W., Y. H. Schukken, M. Nielen, and A. Brand. 2000a. Low somatic cell count: A risk factor for subsequent clinical mastitis in a dairy herd. J. Dairy Sci. 83:1248-1255.

Suriyasathaporn, W., C. Heuer, E. N. Noordhuizen-Stassen, and Y. H. Schukken. 2000b. Hyperketonemia and the impairment of udder defense: A review. Vet. Res. 31:397-412.

Valde, J. P., M. L. Lystad, and E. Simensen. 2007. Comparison of feeding management and body condition of dairy cows in herds with low and high mastitis rates. J. Dairy Sci. 90:43174324. 